\title{
Morphometric Analysis and Pattern of Protein and Gene Expression of Apoptosis in Focal Cerebral Ischemia in Rats and the Neuroprotetive Action of Hypothermia and Ketoprofen
}

\author{
Análisis Morfométrico y Modelo de Expresión de Proteína y Genes de Apoptosis en Isquemia \\ Cerebral Focal en Ratas y la Acción Neuroprotectora de Hipotermia y Ketoprofeno \\ Daniela P. C. Tirapelli ${ }^{1}$; Mucio Luiz de Assis Cirino ${ }^{1}$; Camila A. Melo de Carvalho ${ }^{1}$; Paulo Cezar Novais ${ }^{1,3}$; Rafael Zimak \\ Figueredo $^{1}$; Lucas Barbosa Porsani ${ }^{1}$; Isabella Stracieri Gula ${ }^{1}$; Andressa Romualdo Rodrigues ${ }^{1}$; Jairo Pinheiro da Silva ${ }^{1}$; \\ Adriana Lis Pereira $^{1}$; Fermino Sanches Lizarte Neto ${ }^{1}$; Bruno Cesar Schimming ${ }^{2}$; Maria de Fátima Galli Sorita Tazima ${ }^{1}$; \\ Valéria de Paula Sassoli Fazan ${ }^{1}$; Carlos Gilberto Carlotti Jr. ${ }^{1}$; Luis Fernando Tirapelli ${ }^{1}$ \& Benedicto Oscar Colli ${ }^{1}$
}

TIRAPElli, D. P. C.; CIRINO, M. L. A.; CARVALhO, C. A. M.; NOVAIS, P. C.; FIGUEREDO, R. Z.; PORSANI, L. B.; GULA, I. S.; RODRIGUES, A. R.; SILVA, J. P.; PEREIRA, A. L.; NETO, F. S. L.; SCHIMMING, B. C.; TAZIMA, M. F. G. S.; FAZAN, V. P. S.; CARLOTTI, JR., C. G.; TIRAPELLI, L. F. \& COLLI, B. O. Morphometric analysis and pattern of protein and gene expression of apoptosis in focal cerebral ischemia in rats and the neuroprotetive action of hypothermia and ketoprofen. Int. $J$. Morphol., 38(3):523-529, 2020.

SUMMARY: This study aimed to investigate the morphometric and the pattern of protein and gene expression related to the extrinsic apoptotic pathway in experimental focal cerebral ischemia and the hole of neuroprotection with hypothermia and ketoprofen. For this analysis, 120 rats were randomly divided into 3 groups (20 animals each): control - no surgery (20 animals); sham - simulation of surgery (20 animals); ischemic - focal ischemia for 1 hour, without reperfusion ( 80 animals) and divided into four subgroups with 20 animals each: ischemic + intraischemic hypothermia; ischemic + previous intravenous ketoprofen, and ischemic + hypothermia and ketoprofen. The infarct volume was measured using morphometric analysis of infarct areas defined by triphenyl tetrazolium chloride and the patterns of expression of the apoptosis genes (Fas, c-Flip, caspase- 8 and caspase- 3 ) and the apoptosis protein caspase- 3 were evaluated by quantitative real-time PCR and immunohistochemistry, respectively. Hypo expression of genes of extrinsic pathway of apoptosis was observed: Fas receptor, c-Flip and caspase- 8 in the ischemics areas. Increases in the gene and protein caspase- 3 in the ischemic areas were also observed, and these increases were reduced by hypothermia and ketoprofen, also noted in the morphometric study. The caspases-3 increase suggests that this gene plays an important role in apoptosis, probably culminating in cell death and that the neuroprotective effect of hypothermia and ketoprofen is involved.

KEY WORDS: Apoptosis; Gene expression; Caspase-3; Cerebral ischemia; Neuroprotection; Hypothermia; Ketoprofen.

\section{INTRODUCTION}

Despite the democratization of access to information related to the prevention of conditions such as cerebral ischemia, this is one of the main causes of morbidity and mortality worldwide. The costs associated with the occurrence of stroke should reach 240.67 billion by 2030 according to the American Heart Association indicating that the development of therapies that can effectively act in the prevention or containment of the damage of this disease is very necessary. Studies have shown that agents such as hypothermia, neuromodulation therapy, and stem cell therapies should be considered for treatment of stroke and general ischemia (Lee et al., 2018). One of the main processes involved in nerve tissue damage after cerebral ischemia is apoptosis. This receptor recruits to the same aggregate the pro-caspases- 8 which activates the caspases8 in the death-inducing signaling complex (DISC), which in turn can activate the caspases- 1 and caspases- 3 . The last ones will then execute the apoptotic death of the cell. Proteins called c-Flip, with an anti-apoptotic action, act by competing with caspase-8 for DISC binding (Thorburn, 2004).

\footnotetext{
${ }^{1}$ Department of Surgery and Anatomy, Surgical Clinic Program, FMRP-USP, Ribeirao Preto-SP, Brazil.

${ }^{2}$ Department of Anatomy, UNESP, Botucatu - SP, Brazil.

${ }^{3}$ Faculty of Odontology, Unimar, Marilia-SP, Brazil.
} 
TIRAPELli, D. P. C.; CIRINO, M. L. A.; CARVALHO, C. A. M.; NOVAIS, P. C.; FIGUEREDO, R. Z.; PORSANI, L. B.; GULA, I. S.; RODRIGUES, A. R.; SILVA, J. P.; PEREIRA, A. L.; NETO, F. S. L.; SCHIMMING, B. C.; TAZIMA, M. F. G. S.; FAZAN, V. P. S.; CARLOTTI, JR., C. G.; TIRAPELLI, L. F. \& COLLI, B. O. Morphometric analysis and pattern of protein and gene expression of apoptosis in focal cerebral ischemia in rats and the neuroprotetive action of hypothermia and ketoprofen. Int. J. Morphol., 38(3):523-529, 2020.

Several pharmacological procedures have been used in an attempt to reduce the area involved in the ischemic process. Among them, hypothermia, and anti-inflammatory drugs (Asanuma et al., 1997; Dietrich et al., 1999; Dias et al., 2000) and hypothermia in combination with antiinflammatory drugs (Dietrich et al.), has proved to be effective in providing protection after cerebral ischemia. Anti-inflammatory agents are used to attenuate the inflammatory response triggered by the ischemic phenomenon (Dietrich et al.), and neuroprotective agents such as hypothermia, ketoprofen and hypothermia + ketoprofen have proven effective in previous studies in our group. This hypothesis was suggested by the reduction of gene and protein expression of HSP70 (Tirapelli et al., 2010).

This study aimed to investigate the pattern of expression of the genes related to the extrinsic apoptotic pathway (Fas receptor, c-Flip, caspase-8 and caspase-3), in an experimental model of transient focal cerebral ischemia without reperfusion and the hole of neuroprotection with hypothermia and ketoprofen.

\section{MATERIAL AND METHOD}

The experiments were carried out according to the Ethical Principles for Experimental Animals (COBAO) and the study was approved by the Animal Experimentation Committee (CETEA) of the Faculty of Medicine of Ribeirão Preto, University of São Paulo (Protocol n ${ }^{\circ}$ 0347/2005). One hundred and twenty adult male rats (Rattus norvegicus) weighing 280-310 $\mathrm{g}$ were used. The animals were randomly divided into 3 experimental groups: control (C), 20 animals sacrificed without being submitted to the surgical procedure; sham (S), 20 control animals submitted to complete simulation of the surgical procedure but without obstruction of the middle cerebral artery (MCA) and then sacrificed, and ischemic (I), 80 animals submitted to focal ischemia by occlusion of the MCA for 1 hour and then sacrificed. This group was subdivided into 4 subgroups of 20 animals each: ischemic subgroup (Sg I), ischemic subgroup submitted to hypothermia $(\mathrm{Sg} \mathrm{IH})$, ischemic subgroup treated with ketoprofen (Sg IK), and ischemic subgroup submitted to hypothermia and treated with ketoprofen (Sg IHK). Ten animals from each experimental group, for a total of 60 animals, were used for the delimitation of the ischemic area using a morphometric method for controlling of the efficacy and extension of the ischemia.

Induction of Cerebral Ischemia. All animals were partially anesthetized by halothane inhalation and intubated with an orotracheal cannula. At two times during the ischemic period, arterial blood samples were collected for the determination of glycemia, $\mathrm{paCO}_{2}, \mathrm{paO}_{2}$ and $\mathrm{pH}$. The animals in the $\mathrm{Sg} \mathrm{IH}$ subgroup were submitted to moderate intra-ischemic hypothermia $\left(32-34{ }^{\circ} \mathrm{C}\right)$ by anesthesia itself and by air conditioning the room, the animals in the Sg IK subgroup received an intravenous injection of ketoprofen at the dose of $10 \mathrm{mg} / \mathrm{kg}$ body weight 5 minutes before the induction of ischemia, and the animals in the Sg IHK subgroup were submitted to intra-ischemic hypothermia and similarly injected with ketoprofen. MCA occlusion was carried out through the external carotid artery which was ligated cranially and sectioned for the retrograde introduction of a $2.5 \mathrm{~cm}$ long obstructive 4-0 mononylon suture with one end thickened with silicone over an extension of $5 \mathrm{~mm}$ (Carlotti Jr. et al., 2001). The suture was introduced until to reach the common carotid artery and then cranially progressed through the internal carotid artery until to reach and to obstruct the MCA.

Morphometric analysis of infarct volume. Infarct volumes were measured by morphometric analysis of infarct areas that were defined by 2,3,5-triphenyl tetrazolium (TTC). The brains of the animals were removed and cut into coronal sections using a rat brain matrice and were placed in a $2 \%$ solution of the dye TTC, developed at $37^{\circ} \mathrm{C}$ for 30 minutes, and then stored in $10 \%$ buffered formalin solution. Crosssectional area of the TTC-stained region for each brain slice was determined using an image analyzer (Axion vision 4.6 - Carl Zeiss). After integration of these stained areas, the indirect method of Swanson et al. (1990) was used to determine infarct volume (subtraction of residual left hemisphere cortical volume from the cortical volume of the intact right hemisphere).

\section{Analysis of Protein Expression by} immunohistochemistry. The samples were embedded in paraffin and coronal sections $(3 \mathrm{~mm})$ of the brain were incubated with $3 \% \mathrm{H}_{2} \mathrm{O}_{2}$ and Pierce solution to block endogenous peroxidase and biotin, respectively. Sections were subsequently incubated with primary antibody against caspase-3 (1:200 dilution-CPP32, Novacastra $\left.{ }^{\circledR}\right)$ and with biotin-conjugated secondary anti-rabbit antibody (1:1000; Vector Laboratories Inc., Burlingame, CA) and streptavidinconjugated peroxidase (Vecstatin Abc kit, Vector Laboratories Inc.). Color was developed by the addition of DAB (Sigma Chemical, St. Louis, MO). To evaluate the background reaction, procedures were also performed in sections incubated only with the secondary antibodies (indirect technique) or in the absence antibodies (direct technique). For the analysis of protein expression of caspase3 , a field in an increase of 400x in the area where there was greater concentration of positive cells or marked (areas of "hot spots") was selected in each layer of 
TIRAPELli, D. P. C.; CIRINO, M. L. A.; CARVALHO, C. A. M.; NOVAIS, P. C.; FIGUEREDO, R. Z.; PORSANI, L. B.; GULA, I. S.; RODRIGUES, A. R.; SILVA, J. P.; PEREIRA, A. L.; NETO, F. S. L.; SCHIMMING, B. C.; TAZIMA, M. F. G. S.; FAZAN, V. P. S.; CARLOTTI, JR., C. G.; TIRAPELLI, L. F. \& COLLI, B. O. Morphometric analysis and pattern of protein and gene expression of apoptosis in focal cerebral ischemia in rats and the neuroprotetive action of hypothermia and ketoprofen. Int. J. Morphol., 38(3):523-529, 2020.

immunohistochemical reaction. The number with positive staining for caspase-3 was measured by using a camera (Axio Cam, Zeiss, Germany) and the program Axiovision 4.6 (Zeiss, Germany).

RNA extraction and cDNA synthesis. After removal of the brain, the cortex of the left cerebral hemisphere was isolated and a sample measuring $7 \mathrm{~mm}$ in diameter was punched out for a biopsy centered along the MCA. The samples were placed in cryotubes and stored in liquid nitrogen at $-196^{\circ} \mathrm{C}$ until the time for RNA extraction. For this procedure, 250 $\mathrm{ml} \mathrm{PBS}+750 \mathrm{ml}$ TRIZOL were added to the brain tissue samples which were then lysed in a Polytron homogenizer for about 3 minutes. Next, total RNA was extracted by the TRIZOL method (Invitrogen, Carlsbad, CA, USA) according to manufacturer instructions.

Analysis of Gene Expression Patterns by RQ-PCR. For the quantitative analysis of the genes under study, Fas (Rn 00596168), c-Flip (Rn 00589205), caspase-8 (Rn 00574069) and caspase-3 (Rn 00563902), we used the commercially available system TaqMan Assay-on-demand, which consists of oligonucleotides and probes (Applied Biosystems, Foster City, CA, USA). Reverse transcription was performed using $4 \mathrm{mg}$ total RNA for each sample in $40 \mathrm{~mL}$ of the total reaction mixture, with the addition of oligo (dT)20 (Cat.No. 18418020, Invitrogen) and Superscript II reverse transcriptase (Cat. No. 18064-022, Invitrogen), according to manufacturer instructions. The cDNA obtained was diluted 1:10 and 2.5 $\mathrm{mL}$ was used for each $15 \mathrm{~mL}$ of the RQ-PCR mixture using the TaqMan Master Mix (Applied Biosystems).

$\mathrm{C}$
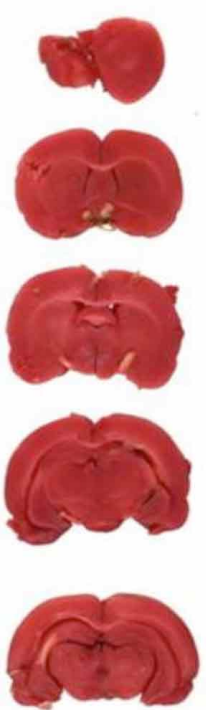
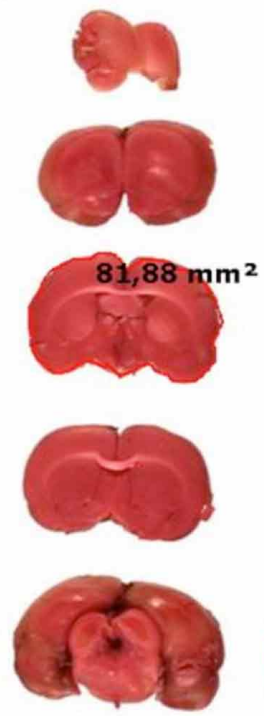
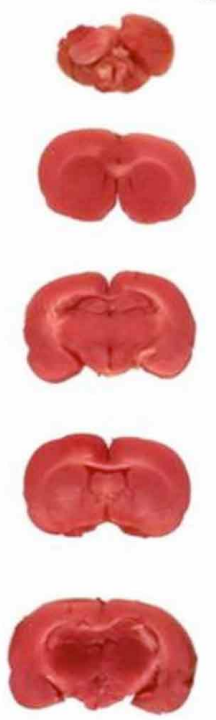

Statistical Analysis. The expression of the genes and protein under study showed normal distribution in the various groups. Data concerning the mean gene and protein expression in the various groups were analyzed statistically by one-way ANOVA followed by the Bonferroni post-test using the GraphPad Prism software, version 4.00 for Windows, (GraphPad Software, San Diego, CA, USA). The level of significance was set at $\mathrm{p}<0.05$ for two-tailed tests.

\section{RESULTS}

The morphometric analysis of rats subjected to a 60 minutes period by occlusion of the MCA showed that the infarct area corresponding to the territory of irrigation of the MCA was clearly observed in the animals of the ischemic group (Fig. 1).

The analysis of the percentage of the volume of ischemic area in relation to the normal hemisphere among the animals of the ischemic group with neuroprotection (SgIH, SgIK and $\mathrm{SgIHK}$ ) revealed a smaller area of infarction in relation to animals of the isquemic subgroup ( $\mathrm{SgI})(\mathrm{p}<0.0001$, one-way ANOVA, $p=0001$, Bonferroni post-test (Fig. 2), and similar areas to that observed in animals of the control group. The mean expression of the Fas, c-Flip and caspase- 8 genes, presented in Figures 3,4 and 5, respectively, was reduced in all groups, with no statistically significant difference between them: Fas ( $\mathrm{p}=$ 0,0768, one-way ANOVA), $c$-Flip ( $p=0,9641$, one-way ANOVA) and caspase-8 ( $\mathrm{p}=0,5643$, one-way ANOVA).

$S$
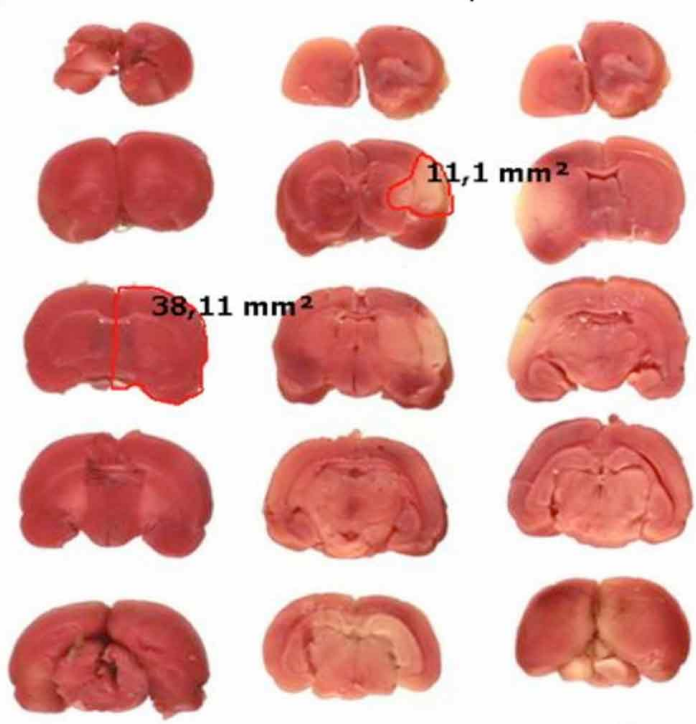

$2 \underline{\mathrm{mm}}$

Fig. 1. Images from the dorsal and ventral views of the coronal sections of the brain of animal control groups (C), sham (S) and ischemic (I), respectively, after staining with TTC. The area of the two brain hemispheres, the right brain hemisphere and the area of infarction are demarcated in red. The left brain hemisphere is seen in cuts 3, 3 and 2. 
TIRAPELLI, D. P. C.; CIRINO, M. L. A.; CARVALHO, C. A. M.; NOVAIS, P. C.; FIGUEREDO, R. Z.; PORSANI, L. B.; GULA, I. S.; RODRIGUES, A. R.; SILVA, J. P.; PEREIRA, A. L.; NETO, F. S. L.; SCHIMMING, B. C.; TAZIMA, M. F. G. S.; FAZAN, V. P. S.; CARLOTTI, JR., C. G.; TIRAPELLI, L. F. \& COLLI, B. O. Morphometric analysis and pattern of protein and gene expression of apoptosis in focal cerebral ischemia in rats and the neuroprotetive action of hypothermia and ketoprofen. Int. J. Morphol., 38(3):523-529, 2020.

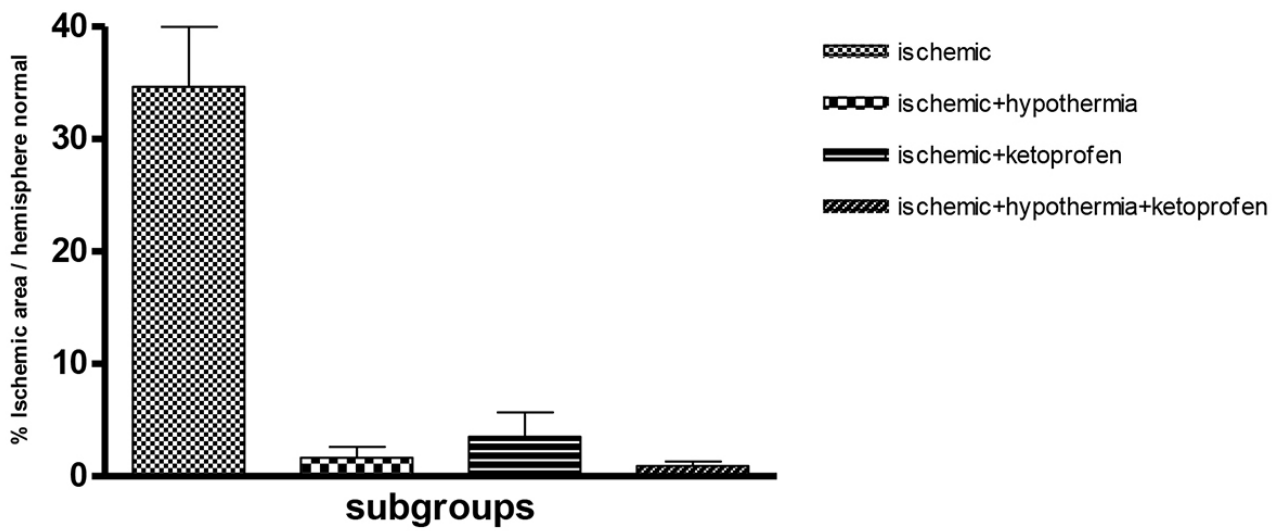

Fig. 2. Percentages of volume of ischemic area in relation to the normal hemisphere among animals of the ischemic group. Significant difference ( $\mathrm{p}<0.0001$, one-way ANOVA, $\mathrm{SgI}>\mathrm{SgIH}, \mathrm{SgIK}$ and $\mathrm{SgIHK}$ : $\mathrm{p}=0.001$, post-test of Bonferroni).

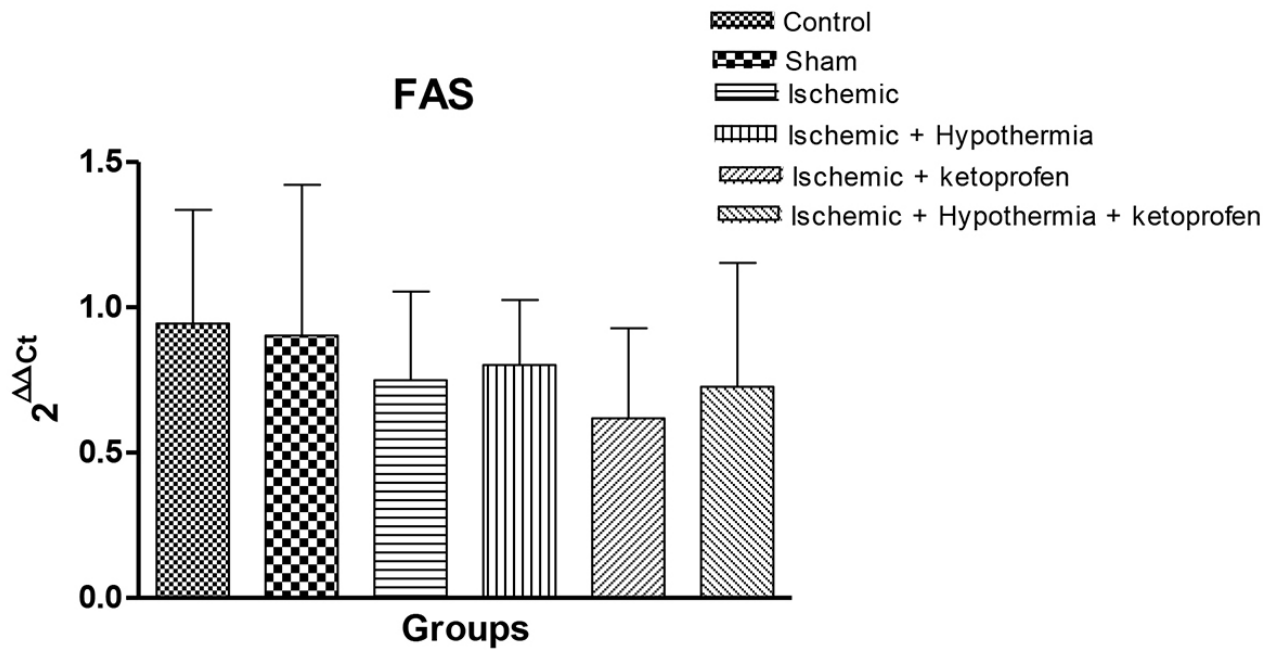

Fig. 3. Gene expression of the Fas receptor gene in the groups studied. Data are reported as means \pm SD.

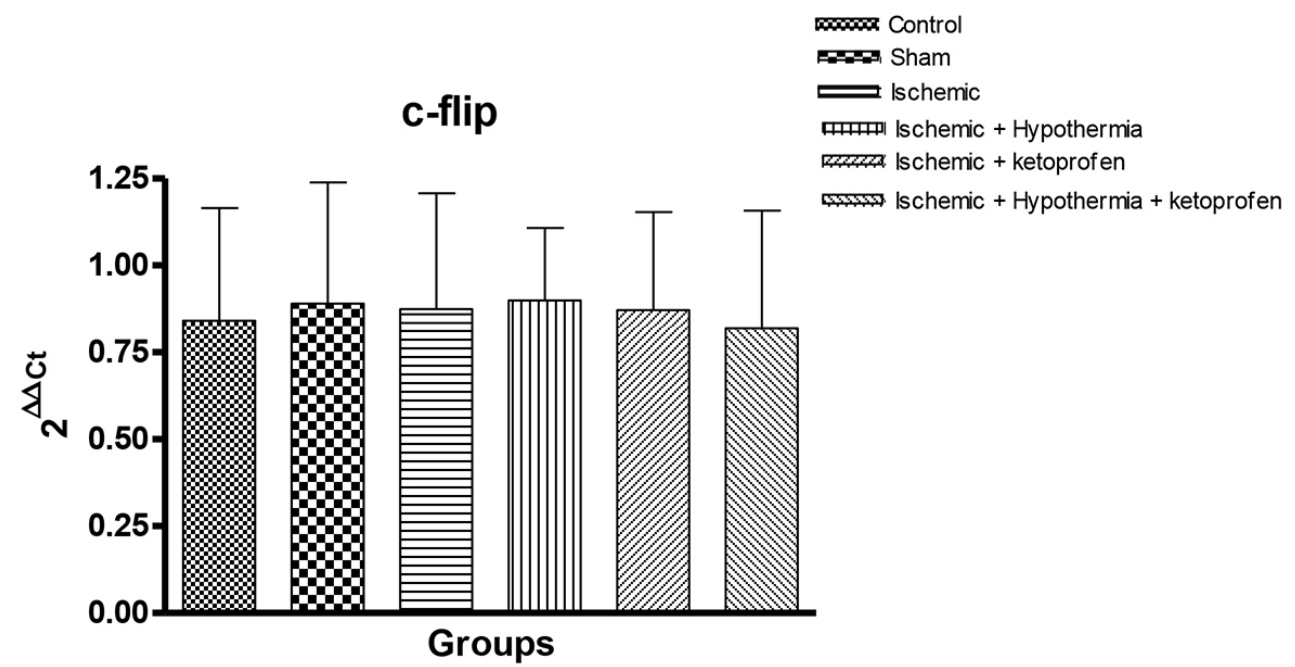

Fig. 4. Gene expression of the c-Flip receptor gene in the groups studied. Data are reported as means \pm SD. 
TIRAPELli, D. P. C.; CIRINO, M. L. A.; CARVALHO, C. A. M.; NOVAIS, P. C.; FIGUEREDO, R. Z.; PORSANI, L. B.; GULA, I. S.; RODRIGUES, A. R.; SILVA, J. P.; PEREIRA, A. L.; NETO, F. S. L.; SCHIMMING, B. C.; TAZIMA, M. F. G. S.; FAZAN, V. P. S.; CARLOTTI, JR., C. G.; TIRAPELLI, L. F. \& COLLI, B. O. Morphometric analysis and pattern of protein and gene expression of apoptosis in focal cerebral ischemia in rats and the neuroprotetive action of hypothermia and ketoprofen. Int. J. Morphol., 38(3):523-529, 2020.

\section{caspase-8}

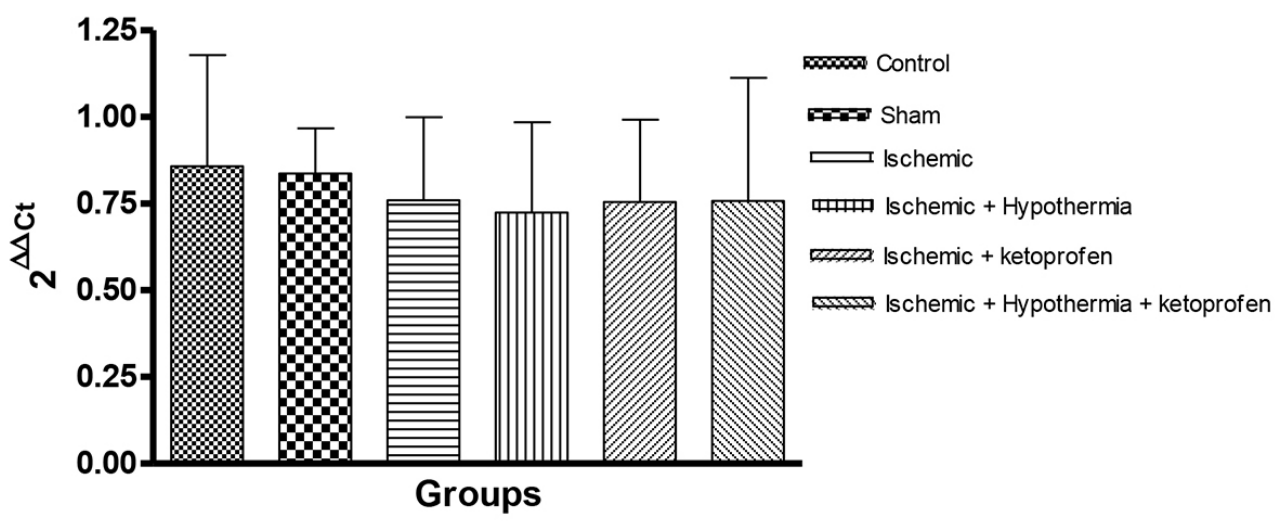

Fig. 5. Gene expression of the caspase- 8 gene in the groups studied. Data are reported as means \pm SD.

Analysis of protein expression of caspase-3 by immunohistochemistry (Fig. 6) showed that in all animals of the group $\mathrm{SgI}$ it was intermediate $(++)$ with the average percentage of positive cells of $41.25 \%$; in group $\mathrm{SgIH}$ it was intermediate $(++)$ for most animals, with low intensity $(+)$ only in animals 3, 4, 6 and 8 and the average percentage of positive cells of $24.06 \%$; in the group SgIK it was low $(+)$ in most animals, with intermediate intensity $(++)$ in animals 2, 4, 6 and 7 and the average percentage of positive cells of $26.22 \%$; and in the group SgIHK expression was low $(+)$ in most animals, with intermediate intensity $(++)$ in animals $1,3,5$ and 7 and with the average percentage of positive cells of $24.15 \%$.

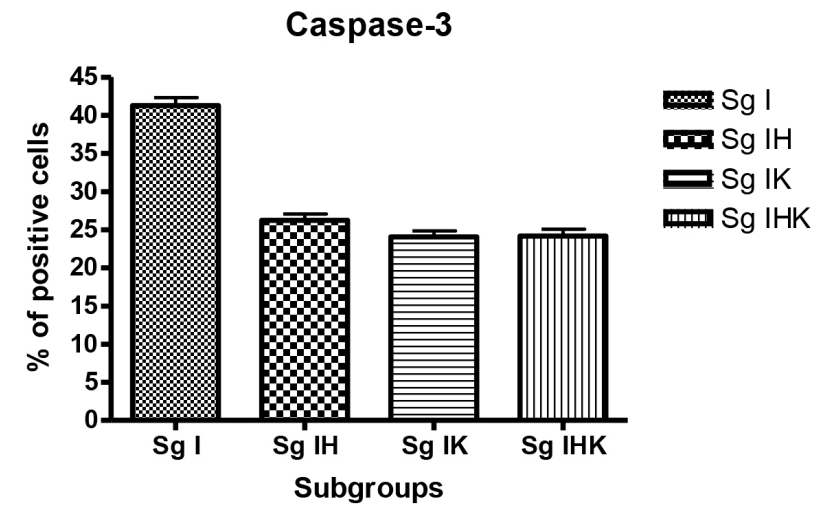

Fig. 7. Mean and standard deviation of the percentage of positive cells to caspase- 3 antibody in the ischemic group.

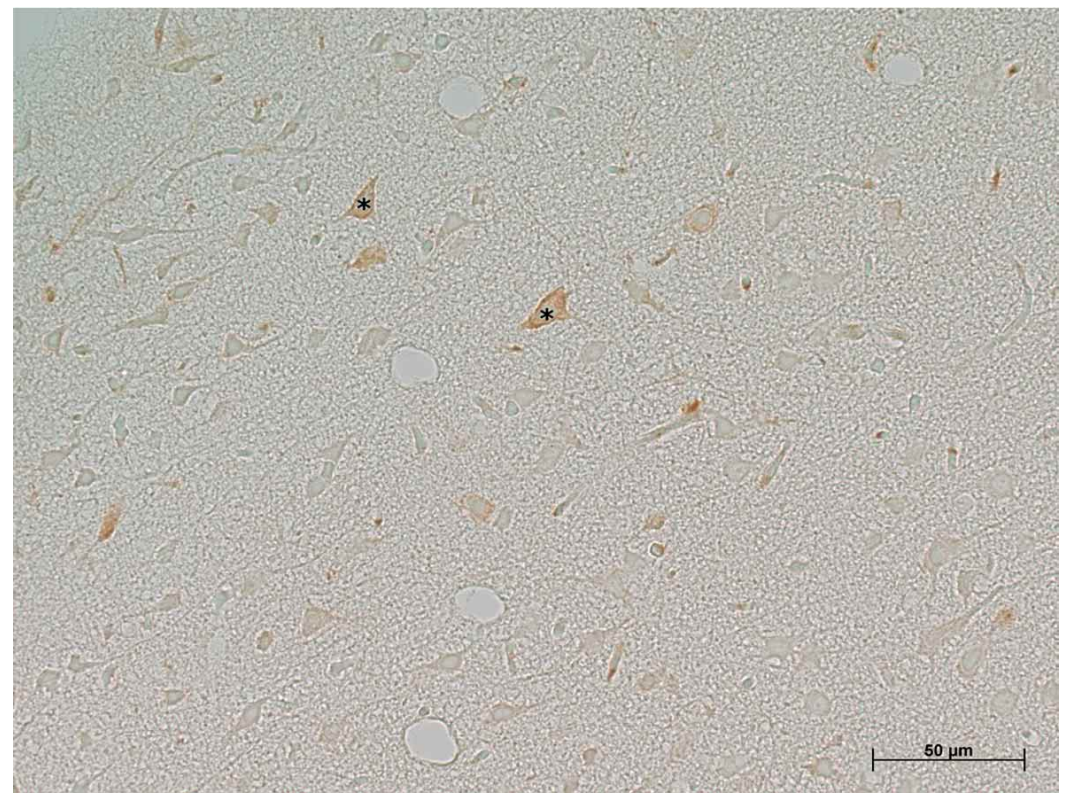

Fig. 6. Photomicrography of the expression of caspase- 3 antibody in the ischemic group. Positive cells in the nervous tissue to the antibody $(*) ;(400 x)$.
Figure 7 shows the mean and standard deviation of the percentage of positive cells to caspase- 3 antibody in the ischemic group. There was statistically significant difference ( $p<0.0001$ one-way ANOVA) between the subgroups SgIxSgIH ( $\mathrm{p}$ $<0.001), \operatorname{SgIxSgIK}(\mathrm{p}<0.001)$ and SgIxSgIHK $(\mathrm{p}<0.001)$, Bonferroni post test. The Figure 8 illustrates the mean expression of the caspase- 3 gene in the experimental groups. The expression in the animals of the ischemic group was higher when compared with control and sham ( $p=0.0001$, one-way ANOVA, $\mathrm{p}<0.05$, Bonferroni post test) and it was lower in the animals of the ischemic treated groups ( $\mathrm{SgIH}, \mathrm{SgIK}$ and $\mathrm{SgIHK}$ ) compared to control, sham and ischemic $(\mathrm{SgI})$ animals $(\mathrm{p}=0.0001$, one-way ANOVA, $\mathrm{p}<0.01$, Bonferroni post-test). 
TIRAPELli, D. P. C.; CIRINO, M. L. A.; CARVALHO, C. A. M.; NOVAIS, P. C.; FIGUEREDO, R. Z.; PORSANI, L. B.; GULA, I. S.; RODRIGUES, A. R.; SILVA, J. P.; PEREIRA, A. L.; NETO, F. S. L.; SCHIMMING, B. C.; TAZIMA, M. F. G. S.; FAZAN, V. P. S.; CARLOTTI, JR., C. G.; TIRAPELLI, L. F. \& COLLI, B. O. Morphometric analysis and pattern of protein and gene expression of apoptosis in focal cerebral ischemia in rats and the neuroprotetive action of hypothermia and ketoprofen. Int. J. Morphol., 38(3):523-529, 2020.

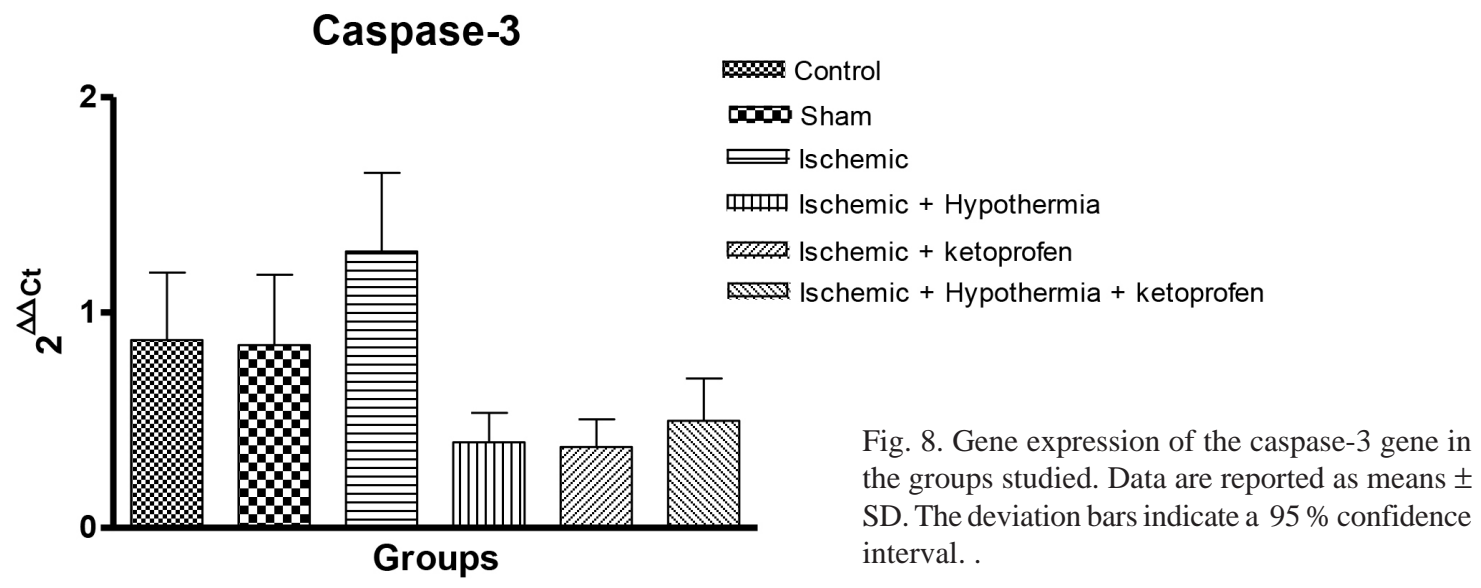

\section{DISCUSSION}

Several morphometric changes are detected in the affected cerebral area after experimental cerebral ischemia, including neuronal and glial cell death by apoptosis (Thorburn, 2004; Matsumori et al., 2005; Siegelin et al., 2005; Zhang et al., 2006). Apoptosis exhibits distinct morphologic characteristics and biochemical changes depending on the pathway through which it occurs.

Protection by hypothermia is associated with inhibition of apoptosis via extracellular or receptor-mediated pathways, i.e., by inhibition of Fas ligand cleavage (FasL). The decrease in soluble FasL presumably inhibits binding and, in turn, reduces the activation of caspase-8. FasL has a protein without a Golgi device called dinamin. One study identified the correlation between hypothermia and its anti-apoptotic effects, suppressing the dynamin (Kim et al., 2017). In our studies, no changes were observed in Fas receptor levels.

Cho et al. (2003) and Kao et al. (2006), observed activation of caspase-8 in rats after the induction of ischemia followed by reperfusion. Matsumori et al. showed that after induction of focal ischemia in transgenic mice there was a reduction of caspase- 8 cleavage, possibly due to the increase in c-Flip, protein inhibitor of apoptosis. Harrison et al. (2001), detected increased mRNA for the Fas receptor accompanied by high levels of expression of mRNA for caspase- 8 . The authors also observed a transitory reduction of caspase- 8 levels in both cerebral hemispheres. This reduction was suggested to be due to an acute effect of the procedure of MCA occlusion and was explained as a response to stress, although the mechanism was not clear. We did not find overexpression of caspases-8, c-Flip and Fas. The low expression of c-Flip was possibly related to the low activation of apoptosis by the extrinsic pathway in the ischemic animals, explaining the low competition between caspase- 8 and c-Flip for DISC binding and the consequent blockade of the apoptotic process (Thorburn et al., 2004). Another hypothesis is that these genes (Fas receptor, caspase- 8 and c-flip) related to the extrinsic pathway of apoptosis were not expressed, because only intrinsic pathway has been activated.

A recent study evaluated some parameters such as neurological deficits, infarct volume and the expression of nestin and caspase- 3 in the hippocampus region after cerebral artery occlusion followed by reperfusion with mild hypothermia treatment. Results demonstrated that hypothermia promoted, among others: significantly survival, reduction in mortality, improvement of neurological deficit score, reduction of cerebral infarction volume, inhibition of apoptosis in the injured hemisphere. In addition, the number of caspase- 3 positive cells correlated with the neurological deficit score, but not with the infarct volume (Yu et al., 2017). These data suggest an important role of caspase 3 in death by apoptosis in ischemic processes. A significant reduction of the activation of caspase- 2 and -3 was observed in studies based on the induction of focal ischemia by the occlusion of the common carotid artery (CCA) in neonatal rats submitted to hypothermia for different periods of post-ischemic reperfusion, indicating a reduction of cerebral apoptotic cell death (Zhu et al., 2006).

We have noticed a decrease in the levels of protein and gene expression of caspase- 3 in the group treated with hypothermia, with ketoprofen and with hypothermia and ketoprofen together. For morphometric analysis, we also observed a decrease in the ischemic area in animals, after treatment with hypothermia, with ketoprofen and with hypothermia and ketoprofen together. The increased expression of caspase- 3 in the ischemic areas and its decrease with the use of neuroprotection, suggest activation of the intrinsic pathway in the ischemic process. 
TIRAPELli, D. P. C.; CIRINO, M. L. A.; CARVALHO, C. A. M.; NOVAIS, P. C.; FIGUEREDO, R. Z.; PORSANI, L. B.; GULA, I. S.; RODRIGUES, A. R.; SILVA, J. P.; PEREIRA, A. L.; NETO, F. S. L.; SCHIMMING, B. C.; TAZIMA, M. F. G. S.; FAZAN, V. P. S.; CARLOTTI, JR., C. G.; TIRAPELLI, L. F. \& COLLI, B. O. Morphometric analysis and pattern of protein and gene expression of apoptosis in focal cerebral ischemia in rats and the neuroprotetive action of hypothermia and ketoprofen. Int. J. Morphol., 38(3):523-529, 2020.

\section{CONCLUSIONS}

The increase in the pro-apoptotic caspase-3 gene expression observed in the ischemic animals was reduced by neuroprotection (hypothermia and ketoprofen). The caspases-3 increases in the ischemic area suggests that culminating in cell death and that the neuroprotective effect of both, hypothermia and ketoprofen is directly involved with the caspase-3.

ACKNOWLEDGMENTS. This study was supported by FAPESP (Fundação de Amparo à Pesquisa do Estado de São Paulo) grant 2005/00381-8.

TIRAPELLI, D. P. C.; CIRINO, M. L. A.; CARVALHO, C. A. M.; NOVAIS, P. C.; FIGUEREDO, R. Z.; PORSANI, L. B.; GULA, I. S.; RODRIGUES, A. R.; SILVA, J. P.; PEREIRA, A. L.; NETO, F. S. L.; SCHIMMING, B. C.; TAZIMA, M. F. G. S.; FAZAN, V. P. S.; CARLOTTI, JR., C. G.; TIRAPELLI, L. F. \& COLLI, B. O. Análisis morfométrico y modelo de expresión de proteína y genes de apoptosis en isquemia cerebral focal en ratas y la acción neuroprotectora de hipotermia y ketoprofeno. Int. J. Morphol., 38(3):523-529, 2020.

RESUMEN: Este estudio tuvo como objetivo investigar la morfometría y el patrón de expresión de proteínas y genes relacionados con la vía apoptótica extrínseca en la isquemia cerebral focal experimental y el agujero de neuroprotección con hipotermia y ketoprofeno. Se dividieron aleatoriamente 120 ratas en 3 grupos (20 animales cada uno): control - sin cirugía (20 animales); simulación - simulación de cirugía (20 animales); isquemia isquemia focal durante 1 hora, sin reperfusión ( 80 animales) y dividida en cuatro subgrupos con 20 animales cada uno: isquemia + hipotermia intraisquémica; isquemia + ketoprofeno intravenoso previo, e isquemia + hipotermia y ketoprofeno. El volumen del infarto se midió utilizando un análisis morfométrico de áreas de infarto definidas por cloruro de trifenil tetrazolio y los patrones de expresión de los genes de apoptosis (Fas, c-Flip, caspase-8 y caspase-3) y la proteína de apoptosis caspase-3 fueron evaluados por PCR cuantitativa en tiempo real e inmunohistoquímica, respectivamente. Se observó hipoexpresión de genes de la vía extrínseca de la apoptosis: receptor Fas, c-Flip y caspasa-8 en las áreas isquémicas. También se observaron aumentos en el gen y la proteína caspasa-3 en las áreas isquémicas y estos aumentos se redujeron por hipotermia y ketoprofeno, también observado por estudio morfométrico. El aumento de caspasas-3 sugiere que este gen tiene un papel importante en la apoptosis, y probable causa de muerte celular, involucrando el efecto neuroprotector de la hipotermia y el ketoprofeno.

PALABRAS ClAVE: Apoptosis; Expresión génica; Caspasa-3; Isquemia cerebral; Neuroprotección; Hipotermia; Ketoprofeno.

\section{REFERENCES}

Asanuma, M.; Asanuma, S. N.; Gómez-Vargas, M.; Yamamoto, M. \& Ogawa, N. Ketoprofen, a non-steroidal anti-inflammatory drug prevents the late-onset reduction of muscarinic receptors in gerbil hippocampus after transient forebrain ischemia. Neurosci. Lett., 225(2):109-12, 1997.

Carlotti Jr., C. G.; Colli, B. O. \& Kazuo, J. Y. Evaluation of brain ischemia by mitochondrial respiration: experimental model. Arq. Neuropsiquiatr., 59(2B):365-71, 2001.

Cho, S.; Liu, D.; Gonzales, C.; Zaleska, M. M. \& Wood, A. Temporal assessment of caspase activation in experimental models of focal and global ischemia. Brain Res., 982(2):146-55, 2003.

Dias, L. A.; Colli, B. O.; Coutinho Netto, J. \& Lachat, J. J. Focal cerebral ischaemia induced by middle cerebral artery occlusion and the neuroprotective effect of ketoprofen in rats. Arq. Neuropsiquiatr., 58(4):1047-54, 2000.

Dietrich, W. D.; Busto, R. \& Bethea, J. R. Postischemic hypothermia and IL-10 treatment provide long-lasting neuroprotection of CA1 hippocampus following transient global ischemia in rats. Exp. Neurol., 158(2):444-50, 1999.

Harrison, D. C.; Davis, R. P.; Bond, B. C.; Campbell, C. A.; James, M. F.; Parsons, A. A. \& Philpott, K. L. Caspase mRNA expression in a rat model of focal cerebral ischemia. Brain Res. Mol. Brain Res., 89(1-2):133-46, 2001.

Kao, T. K.; Ou, Y. C.; Kuo, J. S.; Chen, W. Y.; Liao, S. L.; Wu, C. W.; Chen, C. J.; Ling, N. N.; Zhang, Y. H. \& Peng, W. H. Neuroprotection by tetramethylpyrazine against ischemic brain injury in rats. Neurochem. Int., 48(3):166-76, 2006.

Kim, J. Y.; Kim, N.; Lee, J. E. \& Yenari, M. A. Hypothermia identifies dynamin as a potential therapeutic target in experimental stroke. Ther. Hypothermia Temp. Manag., 7(3):171-7, 2017.

Lee, R. H. C.; Lee, M. H. H.; Wu, C. Y. C.; Silva, A. C.; Possoit, H. E.; Hsieh, T. H Minagar, A. \& Lin, H. W. Cerebral ischemia and neuroregeneration. Neural Regen. Res., 13(3):373-85, 2018.

Matsumori, Y.; Hong, S. M.; Aoyama, K.; Fan, Y.; Kayama, T.; Sheldon, R. A.; Vexler, Z. S.; Ferriero, D. M.; Weinstein, P. R. \& Liu, J. Hsp70 overexpression sequesters AIF and reduces neonatal hypoxic/ischemic brain injury. J. Cereb. Blood Flow Metab., 25(7):899-910, 2005.

Siegelin, M. D.; Kossatz, L. S.; Winkler, J. \& Rami, A. Regulation of XIAP and Smac/DIABLO in the rat hippocampus following transient forebrain ischemia. Neurochem. Int., 46(1):41-51, 2005.

Swanson, R. A.; Morton, M. T.; Tsao-Wu, G.; Savalos, R. A.; Davidson, C. \& Sharp, F. R. A semiautomated method for measuring brain infarct volume. J. Cereb. Blood Flow Metab., 10(2):290-3, 1990.

Thorburn, A. Death receptor-induced cell killing. Cell. Signal., 16(2):139-44, 2004

Tirapelli D. P. C.; Carlotti Jr., C. G.; Leite, J. P.; Tirapelli, L. F. \& Colli, B. O. Expression of HSP70 in cerebral ischemia and neuroprotetive action of hypothermia and ketoprofen. Arq. Neuropsiquiatr., 68(4):592-6, 2010.

Yu, D.; Wang, X.; Zhou, F.; Wang, L.; Yang, G.; Zhong, W.; Li, Y.; Zhou, Z.; Wang, A. \& Zhou, Y. Mild hypothermia modulates the expression of nestin and caspase3 in the sub-granular zone and improves neurological outcomes in rats with ischemic stroke. Oncotarget, 8(65):109191-200, 2017.

Zhang, Z. J.; Li, P.; Wang, Z.; Li, P. T.; Zhang., W. S.; Sun, Z. H.; Zhang, X J. \& Wang, Y. Y. A comparative study on the individual and combined effects of baicalin and jasminoidin on focal cerebral ischemia-reperfusion injury. Brain Res., 1123(1):188-95, 2006.

Zhu, C.; Xu, F.; Wang, X.; Shibata, M.; Uchiyama, Y.; Blomgren, K. \& Hagberg, H. Different apoptotic mechanisms are activated in male and female brains after neonatal hypoxia-ischaemia. J. Neurochem., 96(4):1016-27, 2006.

\section{Correspondence to:}

Daniela P. C. Tirapelli

Medical School

Ribeirão Preto University of São Paulo

Ribeirão Preto 3900

Bandeirantes Avenue - Monte Alegre

CEP: 14049900

BRAZIL

Received: 16-08-2019

Accepted: 23-09-2019

Email: lab.biomol.cirurgia@fmrp.usp.br 